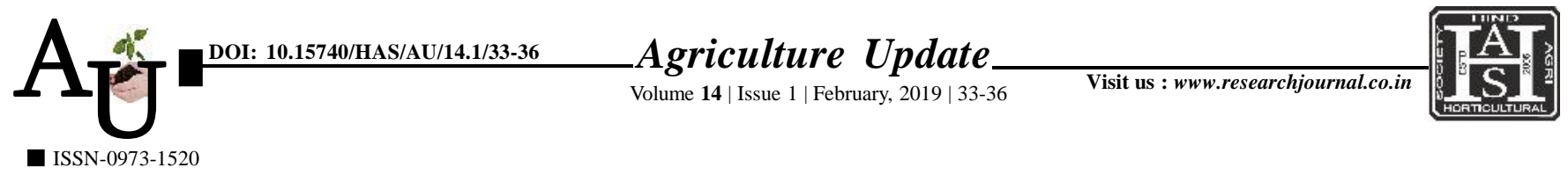

\title{
Research Article: Evaluation of different varieties of onion in Nimar region of Madhya Pradesh
}

\author{
Megha Vibhute and Ajeet Singh
}

Article Chronicle:

Received :

27.11.2018;

Revised :

02.01.2019;

Accepted :

08.01.2019

Key Words :

Onion varieties, On

SUMMARY : Onion varieties were evaluated for adaptability to the climatic conditions in India. It is used both raw and mature bulb stage as vegetable and spice. Three varieties of onion were planted under a Complete Randomized Block Design at farmer field. Successful onion production depends on the selection of varieties that are adapted to different climatic conditions imposed by specific environment. The quantitative data on yield of onion varieties and farmers perception on the varieties were collected. All the varieties were harvested at their maturity ( $80 \%$ top down) and then graded and weighted. The results revealed that highest plant height $(\mathrm{cm})$ was reported from onion variety Agrifound light red $(60.51 \mathrm{~cm})$ and lowest by NHRDF Red-3 $(57.88 \mathrm{~cm})$. Similarly onion variety registered maximum number of leaves NHRDF Red-3 (10.28) and the lowest by Agrifound light red (9.99). Maximum weight of bulb (82.91g) and total yield of bulb (356.0) quintal/hectare was exhibited by var. Bhima Shakti with minimum days taken maturity (126.60) and minimum per cent incidence of bolting (1.66\%). The cultivar Bhima Shakti and NHRDF Red-3 performed well for the Nimar region of Madhya Pradesh in Rabi season.

farm evaluation,

Growth, Yield

attributes

How to cite this article : Vibhute, Megha and Singh, Ajeet (2019). Evaluation of different varieties of onion in Nimar region of Madhya Pradesh. Agric. Update, 14(1): 33-36; DOI : 10.15740/HAS/AU/14.1/33-36. Copyright@ 2019: Hind Agri-Horticultural Society.

Author for correspondence : 